\title{
WYKORZYSTANIE NARZĘDZI ZARZĄDZANIE JAKOŚCIĄ W PROCESIE PRODUKCJI POLIGRAFICZNEJ WYBRANEGO OPAKOWANIA
}

Streszczenie: W rozdziale badaniu zostały poddane etapy procesu produkcji wybranego opakowania w przedsiębiorstwie branży poligraficznej. W analizie skupiono się na identyfikacji niezgodności występujących podczas produkcji. Do określenia struktury niezgodności wykorzystano diagram Ishikawy i diagram Pareto- Lorenza. W analizie uzyskanych wyników skupiono się na metodach doskonalenia jakości wybranych opakowań w celu zrealizowania procesu doskonalenia w oparciu o wymagania klienta.

Słowa kluczowe: jakość, doskonalenie, diagram Ishikawy, diagram Pareto- Lorenza, Just In Time, system push, opakowania

\section{Wprowadzenie}

W realiach gospodarki wolnorynkowej zdecydowana większość dostępnych towarów wymaga opakowania, którego funkcja sprowadza się już nie tylko do zabezpieczenia przed zepsuciem, zanieczyszczeniem, obniżeniem jego zawartości, ułatwiania procesów logistycznych i składowania. Opakowanie odgrywa również ważną rolę w identyfikowaniu i odróżnianiu produktów, oddziałując na emocje odbiorców, tworząc wizerunek produktu i marki. Trafne staje się określenie, że „chroni to, co sprzedaje, i sprzedaje to, co chroni” (SZYMCZAK J. 1998). Jednym z najbardziej upowszechnionych surowców używanych w produkcji opakowań jest papier.

Przedmiotem badań są pudełka jednostkowe z tektury litej GC1 $350 \mathrm{~g} / \mathrm{m}^{2}$, zadrukowane w kolorze $\mathrm{CMYK}+0$, laminowane folią matt, uszlachetniane lakierem UV wybiórczo oraz termodrukiem w kolorze złotym. Pudełko jest sklejane w trzech punktach.

\section{Prezentacja przedsiębiorstwa branży poligraficznej}

Drukarnia, w której analizie poddano proces produkcyjny jest producentem opakowań kartonowych dla wiodących marek w Polsce i Europie. Przedsiębiorstwo od ponad 30 lat inwestuje w nowoczesne technologie, proponując szeroki wachlarz

\footnotetext{
${ }^{1}$ doktorant, Politechnika Częstochowska, Wydział Zarządzania, e-mail: iloonasmo@wp.pl

${ }^{2}$ mgr inż., Politechnika Częstochowska, Wydział Zarządzania, Katedra Inżynierii Produkcji i Bezpieczeństwa, e-mail: k.mielczarek@zim.pcz.pl
} 
uszlachetnień druku. Jest jedną $\mathrm{z}$ nielicznych drukarń w Polsce drukujących w najnowszej technologii LED UV na maszynie Heidelberg CD75-5+LX (rysunek 1).

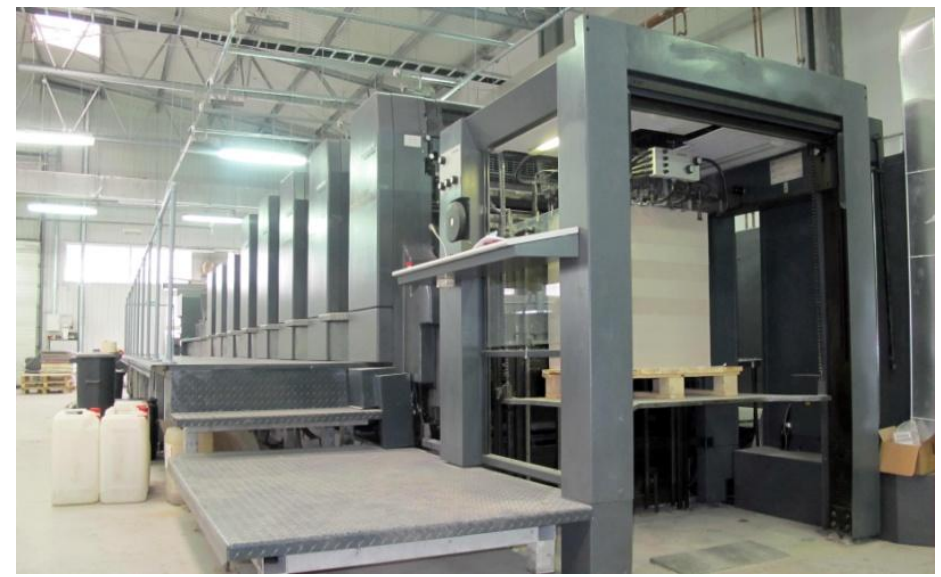

Rys. 1. Maszyna Heidelberg CD75-5+LX”

Źródto: opracowanie własne

Produkcję drukarni charakteryzuje wysoka jakość potwierdzona certyfikatem zgodności $\mathrm{z}$ normą ISO 9001:2008 oraz zaangażowanie $\mathrm{w}$ ochronę środowiska naturalnego potwierdzona certyfikatem Systemu Kontroli Pochodzenia Produktu FSC (PN- EN ISO 9001:2009). Przedsiębiorstwo świadczy usługi: introligatorskie (kaszerowanie, cięcie, wykrawanie, falcowanie), lakierowanie UV (również wybiórczo), druk na metalizie, druk na folii i PCV, tłoczenie (także pisma Braille'a), termodruk (złocenie), klejenie pudełek do 4 punktów klejowych, laminowanie folią, oprawę zeszytową, naświetlanie matryc CTP orazwydruk certyfikowanego proof'a cyfrowego. Drukarnia produkuje pełen wachlarz opakowań takich jak: pudełka jednostkowe z tektur litych i falistych, kartoniki pod blistry (blistercards), opakowania spożywcze $\mathrm{z}$ atestem do kontaktu z żywnością, pudełka na obuwie, pudełka oklejane (rigid boxes), etykiety.

\section{Proces produkcyjny wybranego opakowania}

Przedmiotem badań jest pudełko jednostkowe z tektury litej GC1 $350 \mathrm{~g} / \mathrm{m}^{2}$, zadrukowane $\mathrm{w}$ kolorze $\mathrm{CMYK}+0$, laminowane folią matową, uszlachetniane lakierem UV wybiórczo oraz termodrukiem w kolorze złotym (rysunek 2). Pudełko jest sklejane w trzech punktach. Proces wytwórczy pudełka jednostkowego będącego przedmiotem badań, w zależności od potrzeb, realizowany jest w systemie jedno-, dwu- lub trzyzmianowym. Jest to proces wieloetapowy, złożony, szeregowo 
równoległy, realizowany jednocześnie na kilku działach. Obejmuje takie procesy jak: przygotowanie do druku, skład, naświetlanie płyt CTP, wydanie arkuszy papieru z magazynu, krojenie arkuszy papieru do formatu druku, drukowanie, laminowanie folią matt, termodruk, lakierowanie UV, sztancowanie, obieranie $\mathrm{z}$ ażuru, klejenie, konfekcjonowanie, dystrybucja.

Zwolnienie półproduktu/produktu i przekazanie na kolejny etap procesu produkcyjnego następuje, jeśli $\mathrm{w}$ wyniku zaplanowanego procesu technologicznego zwolniony do następnego etapu półprodukt/produkt jest zgodny $\mathrm{z}$ parametrami określonymi w Karcie Technologicznej oraz jest zgodny ze sztuką drukarską. Zgodność półproduktu/produktu z wymaganiami weryfikowana jest na każdym etapie procesu produkcyjnego poprzez samokontrolę realizujących dany etap procesu oraz potwierdzana pieczęcią Kontroli Jakości.

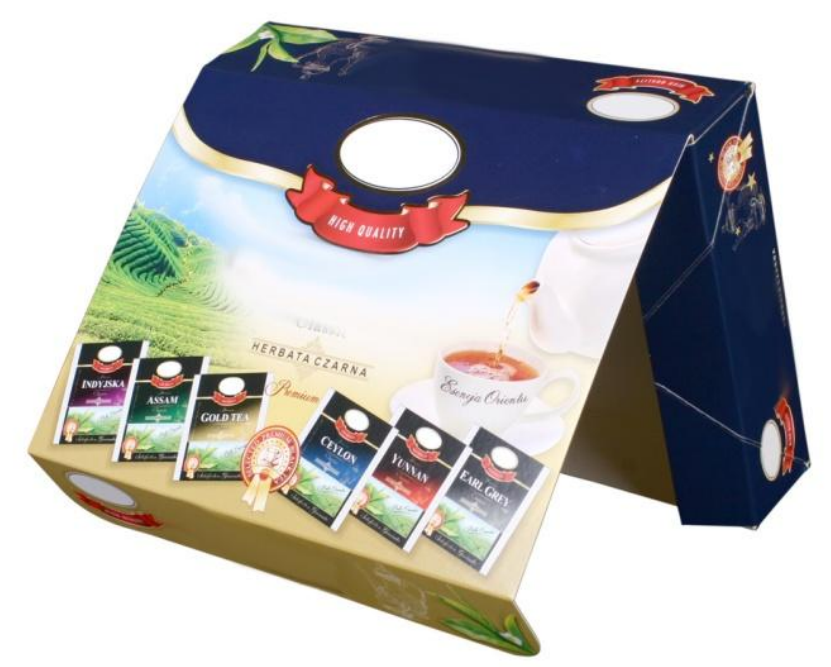

Rys. 2. Przyktadowy wyrób gotowy - pudelko z tektury litej

Źródto: opracowanie własne

Materiały oraz środki do produkcji wydawane są z magazynu na stanowiska produkcyjne do poszczególnych etapów procesu produkcyjnego zgodnie z Just In Time. Prowadzi to do takiej organizacji produkcji, by operacje miały miejsce dokładnie w momencie, kiedy są potrzebne. Półprodukt przekazywany jest do następnego etapu procesu produkcyjnego systemem push. Kontrola i utrzymanie sprawność narzędzi i urządzeń poligraficznych realizowana jest zgodnie z instrukcją I6.3-01 „Nadzór nad utrzymaniem ruchu”. Przedsiębiorstwo nie posiada własnego działu dystrybucji. Logistyka produktu gotowego odbywa się za pośrednictwem 
zewnętrznych firm kurierskich i przewozowych. Produkcja realizowana jest na indywidualne zamówienie klienta. Przedsiębiorstwo nie produkuje na magazyn oraz nie prowadzi sprzedaży B2C. Na rysunku 3. przedstawiono schemat procesu wytwórczego pudełka jednostkowego z tektury litej w ujęciu technologicznym.

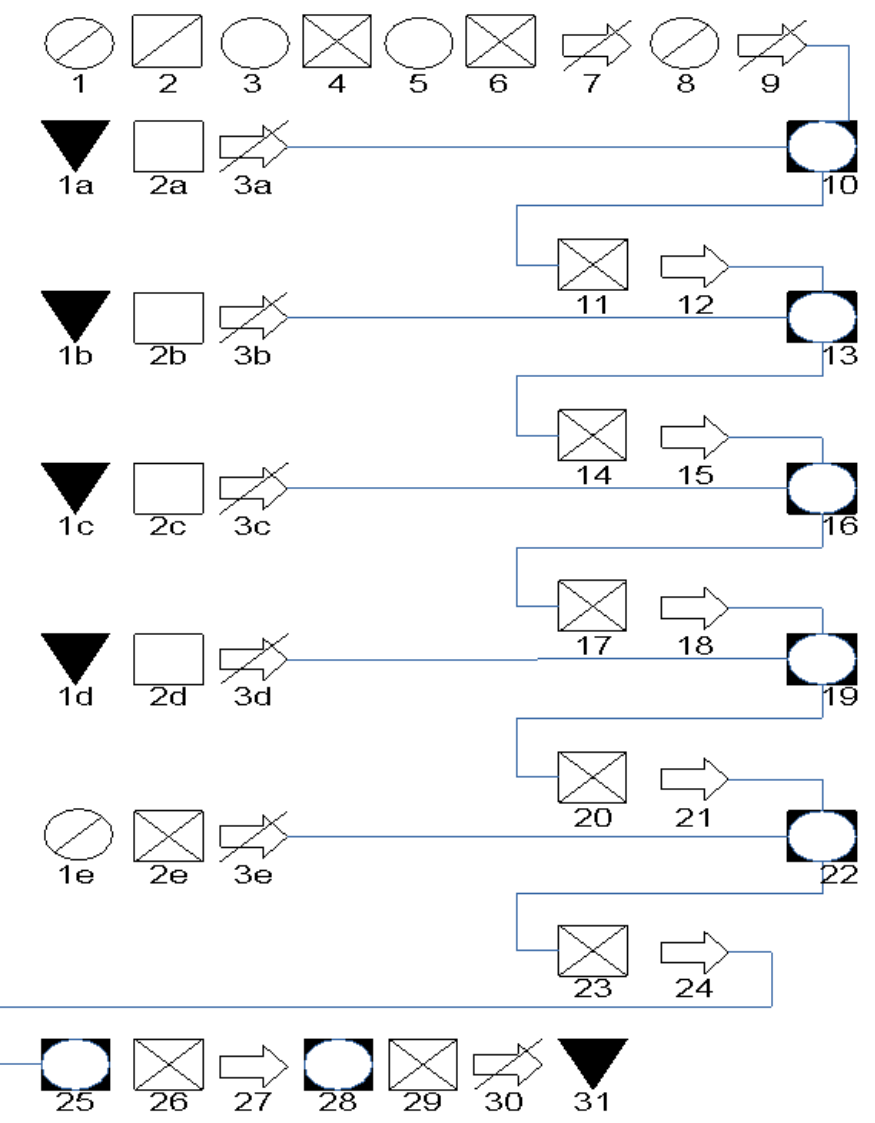

Rys. .3. Proces wytwórczy pudelka jednostkowego z tektury litej w ujęciu technologicznym

Źródto: Opracowanie własne

Proces technologiczny pudełka jednostkowego $\mathrm{z}$ tektury litej składa się z następujących etapów: 1. Przygotowanie do druku materiałów elektronicznych przesłanych przez klienta, 1a. Magazynowanie papieru i farb, 1b. Magazynowanie folii matt do laminacji, 1c. Magazynowania folii złotej do termodruku, 1d. Magazynowanie lakieru UV, 1e. Przygotowanie wykrojnika, 2. Sprawdzenie poprawności przygotowanych materiałów, 2a. Kontrola jakości papieru i farb, $2 b$. Kontrola jakości folii, 2c. Kontrola jakości folii złotej do termodruku, 2d. Kontrola jakości lakieru UV, 2e. Sprawdzenie poprawności wykonania wykrojnika, 
3. Nanoszenie ewentualnych poprawek w materiale elektronicznym przesłanym przez klienta, 3a. Wydanie papieru i farb z magazynu oraz transport do działu maszyn drukujących, 3b. Wydanie folii do laminacji z magazynu oraz transport do działu uszlachetniania, 3c. Wydanie folii do termodruku z magazynu oraz transport do działu uszlachetniania, 3d. Wydanie lakieru UV z magazynu oraz transport do działu uszlachetniania, 3e. Transport wykrojnika do działu introligatorni, 4. Ostateczne sprawdzenie przygotowanych elektronicznych materiałów klienta, 5. Wykonanie montaży, 6. Sprawdzenie montaży, 7. Przekazanie plików z montażami do działu CTP, 8. Naświetlanie i trawienie płyt offsetowych CTP, 9. Przekazanie płyt offsetowych do działu maszyn drukujących, 10. Drukowanie arkuszy, 11. Kontrola jakości, 12. Transport międzyoperacyjny, 13. Laminowanie folią matt wydrukowanych arkuszy, 14. Kontrola jakości, 15. Transport międzyoperacyjny, 16. Termodruk zalaminowanych arkuszy drukarskich, 17. Kontrola jakości, 18. Transport międzyoperacyjny, 19. Lakierowanie wybiórcze lakierem UV, 20. Kontrola jakości, 21. Transport międzyoperacyjny, 22. Sztancowanie arkuszy, 23. Kontrola jakości, 24. Transport międzyoperacyjny, 25. Obieranie użytków z ażuru, 26. Kontrola jakości, 27. Transport międzyoperacyjny, 28. Klejenie i pakowanie pudełek jednostkowych, 29. Kontrola jakości, 30. Transport sklejonych pudełek do magazynu wyrobów gotowych, 31. Magazynowanie gotowych wyrobów.

\section{Struktura niezgodności wybranych opakowań jednostkowych $\mathrm{z}$ tektury litej}

W celu identyfikacji najczęściej występujących niezgodności mających negatywny wpływ na jakość produkowanych opakowań jednostkowych z tektury litej w badanym przedsiębiorstwie zastosowano diagram Pareto-Lorenza (DZIUBA S.T., PieKara A., MaŁas W., KozioŁ P. 2013). Metoda ta należy do technik prowadzących do zidentyfikowania najważniejszych cech (zdarzeń, przyczyn) mających najistotniejszy wpływ na proces produkcji i jakość, a przez to umożliwiających określenie działań zmierzających do poprawy poziomu jakości procesów lub wybranych cech jakościowych wyrobów materialnych i usług (BORKOWSKI S., ULEWICZ R. 2008). Diagram sporządzono dla niezgodności występujących w okresie 12 miesięcy (tabela 1).

Na podstawie danych $\mathrm{z}$ tabeli 1 sporządzono diagram Pareto-Lorenza (rysunek 4). Wynika z niego, że za $71,43 \%$ wad powstałych przy produkcji pudełka jednostkowego odpowiadają trzy niezgodności:

- $\mathrm{N}_{8^{-}}$nadmierny przyrost punktu rastrowego na odbitce,

- $\mathrm{N}_{5}$ - brak pasowania kolorów,

- $\mathrm{N}_{1}$ - odciąganie druków w stosie. 
Przedsiębiorstwo powinno zwrócić uwagę na przebieg procesu drukowania na wydziale maszyn drukujących, ponieważ wyeliminowanie przyczyn niezgodności tam powstałych pozwoli na znaczące obniżenie wskaźnika $71,43 \%$ niezgodności powstałych przy produkcji pudełka jednostkowego z tektury litej.

Tabela 1. Niezgodności wystęujące podczas produkcji opakowań jednostkowych z tektury litej

\begin{tabular}{|c|c|c|c|}
\hline $\begin{array}{c}\text { Symbol } \\
\text { niezgodności }\end{array}$ & $\begin{array}{c}\text { Częstotliwość } \\
\text { wystąpienia niezgodności }\end{array}$ & $\begin{array}{c}\text { Udzial procentowy } \\
\text { niezgodności (\%) }\end{array}$ & $\begin{array}{c}\text { Udzial skumulowany } \\
\text { niezgodności (\%) }\end{array}$ \\
\hline $\mathbf{N}_{\mathbf{8}}$ & 42 & 27,27 & 27,27 \\
\hline $\mathbf{N}_{\mathbf{5}}$ & 35 & 22,73 & 50,00 \\
\hline $\mathbf{N}_{\mathbf{1}}$ & 33 & 21,43 & 71,43 \\
\hline $\mathbf{N}_{\mathbf{2}}$ & 11 & 7,14 & 78,57 \\
\hline $\mathbf{N}_{\mathbf{6}}$ & 11 & 7,14 & 85,71 \\
$\mathbf{N}_{\mathbf{3}}$ & 10 & 6,50 & 92,21 \\
\hline $\mathbf{N}_{\mathbf{7}}$ & 7 & 4,54 & 96,75 \\
$\mathbf{N}_{\mathbf{4}}$ & 5 & 3,25 & 100 \\
\hline & Razem & 100 & ------ \\
\hline
\end{tabular}

Źródto: opracowanie własne

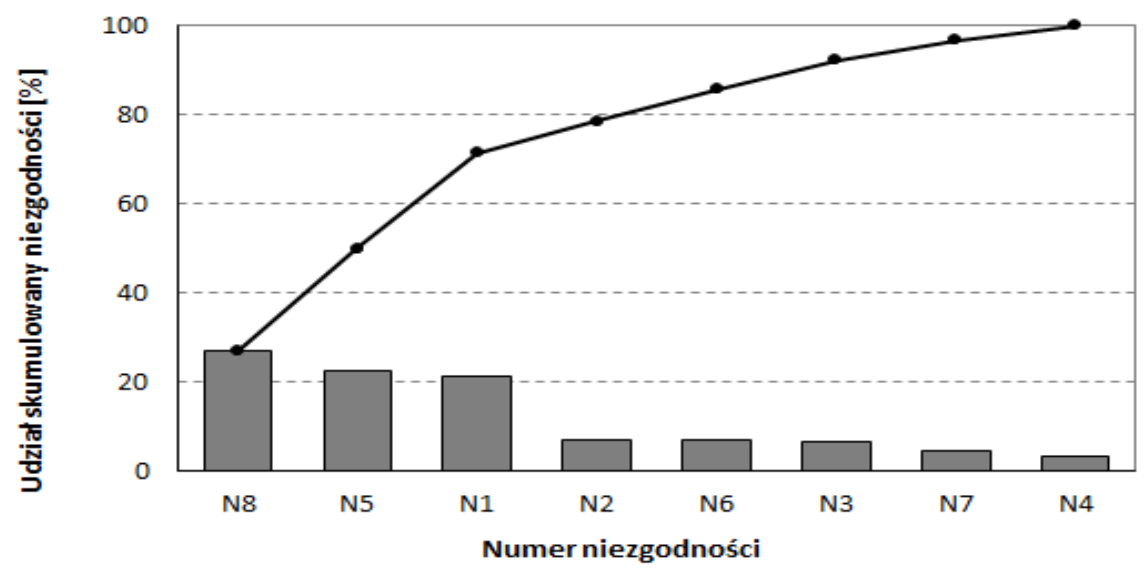

Rys. 4. Diagram Pareto-Lorenza dla niezgodności występujących w procesie produkcji opakowania jednostkowego z tektury litej

Źródlo: opracowanie własne 


\section{Identyfikacja obszarów krytycznych w produkcji wybranych opakowań jednostkowych}

Realizując założenia Politykę Jakości przedsiębiorstwo zapewnia klientom rzetelność i profesjonalizm w zakresie świadczonych usług poligraficznych mając na uwadze ciągły proces doskonalenia wdrożonego Systemu Zarządzania Jakością zgodnego z normą ISO 9001:2008. System ten jest podstawowym narzędziem do planowania i koordynacji działań w obszarach jakości świadczonych usług.

Do zbierania, przetwarzania $\mathrm{i}$ analizy danych związanych $\mathrm{z}$ aspektem jakości służą narzędzia zarządzania jakością, które są instrumentami nadzorowania i diagnozowania procesów produkcyjnych występujących w cyklu wytwarzania wyrobu. Analiza problemów jakościowych produkcji opakowań jednostkowych dotyczy identyfikacji obszarów powstawania niezgodności i określenia ich struktury oraz ważności z punktu widzenia klienta. Znaczące przyczyny wpływające na niezgodności w produkcji wybranych opakowań jednostkowych zostaną wytypowane i przedstawione za pomocą diagramu Ishikawy. Jest on jednym z częściej stosowanych narzędzi w zarządzaniu jakością (BRAJER-MARCZAK R. 2015). $\mathrm{W}$ analizowanym przedsiębiorstwie wyodrębniono pięć grup powstawania niezgodności: metoda, materiał, zarządzanie, maszyna, człowiek. Rysunek 5. przedstawia diagram Ishikawy opracowany dla powstawania niezgodności w produkcji wybranych opakowań jednostkowych.

Analizowanie diagramu pozwala wyodrębnić najważniejsze przyczyny, które maja wpływ na poziom jakości, a co za tym idzie dzięki niemu można określić dla tych przyczyn działania korygująco- zapobiegawcze (BORKOWSKI S. 2004). Największy wpływ na jakość w produkcji wybranych opakowań jednostkowych w badanym przedsiębiorstwie mają dwie grupy przyczyn: metoda (40\%) i człowiek $(30 \%)$. Nie bez znaczenia $\mathrm{w}$ badanym przedsiębiorstwie pozostaje również zarządzanie $(15 \%)$ jako trzecia z kolei grupa przyczyn mająca wpływ na jakość produkcji badanych wybranych opakowań jednostkowych. Dla zidentyfikowanego problemu poprawy jakości pudełek jednostkowych $\mathrm{z}$ tektury litej $\mathrm{w}$ badanym przedsiębiorstwie, zgodnie z ideą od ogółu do szczegółu, określono przyczyny odpowiedzialne za powstawanie tych problemów. Identyfikacja tych przyczyn umożliwia opracowanie planu działań, który pozwoli zniwelować najbardziej istotne przyczyny mające negatywny wpływ na jakość produkcji badanych wybranych opakowań jednostkowych. 


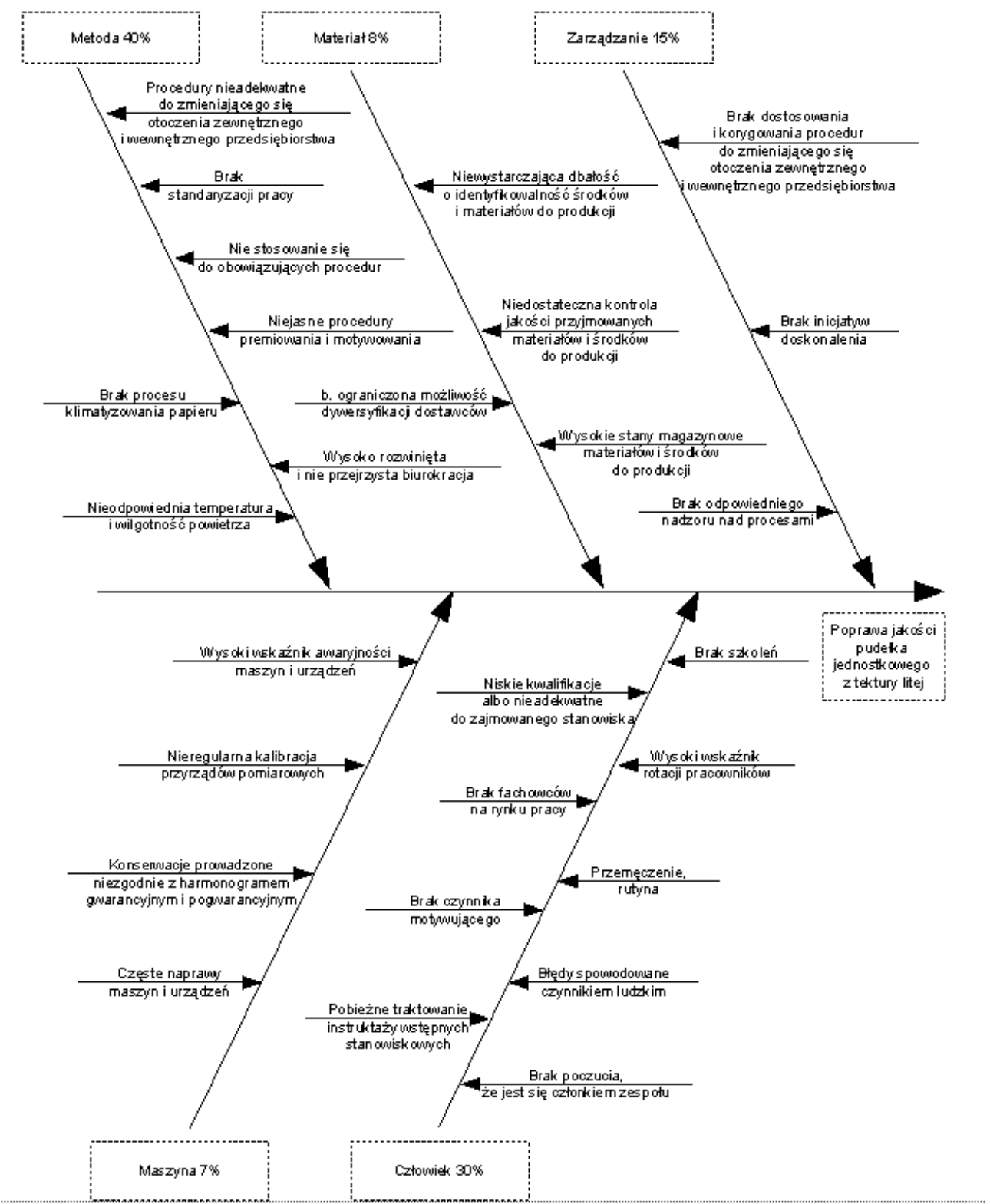

Rys. 5. Diagram Ishikawy - obszary powstawania niezgodności w produkcji wybranych opakowań jednostkowych z tektury litej

Źródto: opracowanie własne

W przedsiębiorstwie zaproponowano następujące działania korygującozapobiegawcze: 
- weryfikacja i aktualizacja przez kierownictwo obowiązujących procedur dostosowanych do zmieniającego się otoczenia zewnętrznego i wewnętrznego przedsiębiorstwa,

- opracowanie przez kierownictwo systemu rekrutacji i szkoleń pracowników,

- opracowanie i wdrożenie przez kierownictwo przejrzystego systemu premiowania i motywowania,

- pobudzanie inicjatyw oddolnych doskonalenia procesów przez pracowników,

- standaryzacja stanowisk i organizacji pracy,

- audyty procesów.

\section{Podsumowanie}

Złożoność otoczenia i dynamicznie zachodzące $\mathrm{w}$ nim zmiany powodują, że przedsiębiorstwa, żeby zrealizować potrzeby klienta, budują łańcuchy dostaw, które wzajemnie się przenikają. Kluczem do sukcesu organizacji stają się czas, elastyczność, zapasy i koszty, zarządzanie wiedzą, kompetencje organizacji jako całości oraz jakość oferowanych wyrobów i usług. Realizacji tego celu służą różne koncepcje, metody i narzędzia kontrolujące i wspomagające procesy zachodzące $\mathrm{w}$ przedsiębiorstwie, w tym procesy produkcyjne. Rola opakowania nie sprowadza się już tylko do zabezpieczenia przed zepsuciem, zanieczyszczeniem, obniżeniem jego zawartości. Opakowanie oddziałuje również na emocje odbiorców tworząc wizerunek produktu i marki. Kluczowym staje się zidentyfikowanie przyczyn powstania niezgodności w produkcji opakowań jednostkowych $\mathrm{z}$ tektury litej w badanym przedsiębiorstwie poligraficznym oraz podjęcie działań korygująco- naprawczych w celu zminimalizowania i wyeliminowania potencjalnych przyczyn występowania tych niezgodności.

Diagram Pareto - Lorenza wskazał, że w trakcie procesu drukowania na wydziale maszyn drukujących wyeliminowanie przyczyn niezgodności tam powstałych pozwoli na znaczące obniżenie wskaźnika 71,43\% wad powstałych przy produkcji pudełka jednostkowego z tektury litej. Wyniki uzyskane na podstawie diagramu Ishikawy wskazują, iż największy wpływ na jakość w produkcji wybranych opakowań mają dwie grupy przyczyn: metoda (40\%) i człowiek (30\%).

Na podstawie uzyskanych danych należy opracować oraz wdrożyć odpowiedni system kontroli jakości weryfikując i aktualizując obowiązujące procedury dostosowując je do zmieniającego się otoczenia zewnętrznego i wewnętrznego przedsiębiorstwa. Standaryzacja druku wg normy ISO 12647-2 oraz podjęcie kroków w celu stosowania elementów filozofii Kaizen to jedne z najważniejszych działań, na które przedsiębiorstwo powinno skierować swą uwagę. 


\section{Bibliografia}

1. Borkowski S., UlewiCZ R. 2008. Zarzadzanie produkcją. Systemy produkcyjne. Wydawnictwo Humanitas. Sosnowiec.

2. BORKOWSKI S. 2004. Mierzenie poziomu jakości. Wydawnictwo Wyższa Szkoła Zarządzania i Marketingu w Sosnowcu. Sosnowiec.

3. BRAJER-MARCZAK R. 2015. Doskonalenie zarzadzania jakościa procesów i produktów w organizacjach. Wydawnictwo Uniwersytetu Ekonomicznego we Wrocławiu. Wrocław.

4. Dziuba S.T., Piekara A., MaŁas W., Kozioł P. 2013. Traditional tools of quality improvement used to improve furniture production process. [w:] Quality Control Meaning in Products and Processes Improvement, chapter 6. Ed. S. Borkowski, P. Sygut. University of Maribor, Faculty of Logistics, Celje 2013.

5. PN-EN ISO 9001:2009- Systemy zarządzania jakościa- Wymagania. Polski Komitet Normalizacyjny, Warszawa 2009.

6. SZYMCZAK J. 1998. Promocyjne funkcje opakowań jednostkowych. Opakowanie. nr 2, 